\title{
Students' pro-environmental behavior and environmental learning outcomes based on green consumerism
}

\author{
IImi Zajuli Ichsan a,1, Diana Vivanti Sigit a,2,", Mieke Miarsyah a,3, Eka Putri Azrai a,4, Erna Heryanti a,5 \\ ${ }^{a}$ Department of Biology Education, Faculty of Mathematics and Natural Science, Universitas Negeri Jakarta, Jl.Rawamangun Muka, \\ the Special Capital Territory of Jakarta (DKI, Jakarta) 13220, Indonesia \\ 1 ilmizajuli95@gmail.com; 2 dianav@unj.ac.id *; 3 mmiarsyah@unj.ac.id; ${ }^{4}$ ekaputri@unj.ac.id; 5 erna.heryanti@gmail.com \\ * corresponding author
}

\begin{tabular}{|c|c|}
\hline ARTICLE INFO & ABSTRACT \\
\hline \multirow[t]{2}{*}{$\begin{array}{l}\text { Article history } \\
\text { Received August 19, } 2018 \\
\text { Revised February 13, } 2019 \\
\text { Accepted February 23, } 2019 \\
\text { Published February 28, } 2019\end{array}$} & $\begin{array}{l}\text { Green consumerism has been considered as one of promising movement in } \\
\text { maintaining the environmental quality. This research aimed to describe the students' } \\
\text { pro-environmental behavior (PEB) as considerable as there learning outcome based on } \\
\text { green consumerism. This survey research was conducted in State Junior High School } 1 \\
\text { of South Tambun, Bekasi, West Java on July-August } 2018 \text {. The sampling technique } \\
\text { used was simple random sampling with } 256 \text { students. The subject was divided into two } \\
\text { groups: } 128 \text { students from seventh grade who had not received environmental learning } \\
\text { materials and } 128 \text { students from eighth grade who had received environmental learning } \\
\text { materials. The data analysis used in this study was an independent t-test. The results of } \\
\text { the t-test showed that there was no significant difference of PEB achievement between } \\
\text { the two groups. In addition, not with standing that the average of the students' } \\
\text { environmental learning outcomes was } 72.76 \text {, but there was as high as } 78.60 \% \text { of } \\
\text { students' achievement was classified below the standard value. Thus, teachers should } \\
\text { evaluate the environmental materials used. It is expected that Biology subjects on } \\
\text { environmental material can accommodate green consumerism concepts. }\end{array}$ \\
\hline & $\begin{array}{r}\text { Copyright } \odot \text { 2019, Ichsan et al } \\
\text { This is an open access article under the CC-BY-SA license }\end{array}$ \\
\hline $\begin{array}{l}\text { environmente } \\
\text { 109-116. doi: }\end{array}$ & $\begin{array}{l}\text { liarsyah, M., Azrai, E.P., \& Heryanti, E. (2019). Students' pro-environmental behavior and } \\
\text { tcomes based on green consumerism. JPBI (Jurnal Pendidikan Biologi Indonesia), 5(1), } \\
\text { g/10.22219/jpbi.v5i1.6447 }\end{array}$ \\
\hline
\end{tabular}

\section{INTRODUCTION}

Waste in the environment is one of the environmental problems that are of concern to the community. The school environment is one of the environments of concern because many school canteens are not yet environmentally friendly. Students are important subjects in research about the school environment because it has a role in protecting the environment, students who have good achievements are usually associated with their perception in protecting the environment (Cheng, Wong, Wearing, \& McDonald, 2017; Choudri et al., 2017; Sandilos, Rimm-Kaufman, \& Cohen, 2017). In addition to the garbage scattered in the environment, the management is still very minimal. A lot of households don't care about garbage from their household. Their 
vegetables and food ingredients are usually left to rot and are not cleaned in the right way (McCarthy \& Liu, 2017).

In addition to waste problems, there are other problems in the environmental field. One of them is environmental damage that adversely affects living things (Burrascano et al., 2016; Margono, Potapov, Turubanova, Stolle, \& Hansen, 2014). This is of concern given that forests are the center of natural resources. The destruction of this forest cannot be avoided. One simple effort that might be made so that the forest does not continue to be cut down by saving paper, for example, does not use products made of wood and starts to switch to recycled wood and so on. All of the various efforts made by each person can be outlined in various policies implemented by the government and wood processing companies to find alternatives to make paper production cleaner and more environmentally friendly (Akenji, 2014; Silva, Pavan, Oliveira, \& Ometto, 2015).

Environmental problems in Indonesia can be overcome one of them through learning in school. It is proven that students can make a craft to reduce plastic waste (Ichsan \& Mulyani, 2018; McCarthy \& Liu, 2017). Various forms of activities can be carried out so that students understand the importance of the environment for survival in the future. These problems can, in general, be overcome if students understand the concept of green consumerism. Green Consumerism encompasses all activities that are essentially a person's commitment to consuming environmentally friendly products (Haws, Winterich, \& Naylor, 2014; Lekakos, Vlachos, \& Koritos, 2014; Moisander, 2007). Some activities related to green consumerism such as turning off lights during sleep, using public transportation that is environmentally friendly, minimizing plastics and many others.

This pro-environmental behavior (PEB) is very closely related to green consumerism. Pro-environmental behavior is a behavior that is formed from habits carried out by someone towards the environment. This behavior depends on many very complex aspects, such as making policies on environmentally friendly products, income, and time efficiency (Ertz, Karakas, \& Sarigöllü, 2016). This study does not discuss proenvironmental behavior from a broader aspect, we focus on the discussion of PEB and green consumerism in terms of learning in schools.

Learning about green consumerism can be conveyed in Biology learning about environmental material in the 7th semester of even semester. The role of learning in this material is very important because it is a time that is considered appropriate to convey green consumerism concepts. Material about green consumerism can be conveyed with various learning media such as books, learning videos, websites and so on. Now, learning the environment at any time does not have to come to class (Gündüz, Alemdağ, Yaşar, \& Erdem, 2016; Nissim, Weissblueth, Scott-Webber, \& Amar, 2016; Snake-Beings, 2017).

\section{METHOD}

The method used in this study is a descriptive method with a survey. The sample used in this study were 256 students who had done simple random sampling, which consisted of 128 grade 7 students and 128 grade 8 students. When the research was in July-August 2018 located at State Junior High School 1 of South Tambun, Bekasi, West Java. Data analysis used in this study is normality test using the Kolmogorov Smirnov test and homogeneity test using the $\mathrm{F}$ test. Then hypothesis used independent $\mathrm{t}$-test with a $95 \%$ confidence level.

The instrument grid used in this study is quoted from Kaiser \& Wilson (2004) a little modification, because the sentence on the instrument is adjusted to the characteristics of the sample used. The number of items used in the instrument is 15 items that are valid and reliable. Little modification is done in the context of the use of words on the instrument to match the sample used. This is done to better suit the level of understanding of junior high school students. More details can be seen in Table 1.

Table 1. An aspect of pro-environmental behavior instruments.

\begin{tabular}{ccc}
\hline No & Aspect & Item \\
\hline 1 & Energy Conservation & 1,2 \\
2 & Transportation & $3,4^{*}$ \\
3 & Waste Avoidance & 5,6 \\
4 & Consumerism & $7,8,9^{*}, 10^{*}$ \\
5 & Recycling & 11,12 \\
6 & Vicarious, Social Behavior & $13,14,15$ \\
\hline
\end{tabular}

*: negative item 
This study contains the research hypothesis as follows: $\mathrm{H}_{0}$ : There is no difference in scores on students' pro-environmental behavior between grade 7 and grade 8; and $\mathrm{H}_{1}$ : There is the difference in scores on students' pro-environmental behavior between grade 7 and grade 8 .

\section{RESULT AND DISCUSSION}

The results of calculating the average PEB score between class 7 and class 8 show results that are not much different. The average PEB score of the 7 th-grade students is at 63.35 and 8 th grade at 64.17 . The following is a graph of the average PEB score of 7 th and 8th-grade junior high school students at 64.17 with a score range of 0-100. More clear results can be seen in the Figure 1.

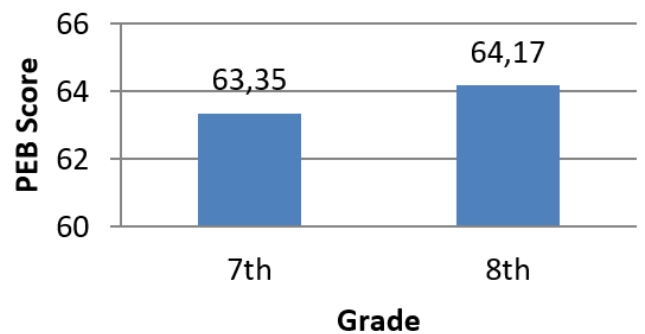

Figure 1. The average score of pro-environmental behavior for junior high school students is 7 th and 8 th grade

The average score between grade class 7 and class 8 was carried out by the comparison test. The comparative test is done to see how significant the difference in scores between class 7 and class 8 . The results of the t-test can be seen in Table 2 .

Table 2. The results of t-test scores of pro-environmental behavior Students between grades 7 and grade 8

\begin{tabular}{cccc}
\hline $\mathrm{T}$ & $\mathrm{df}$ & Sig. & Mean Difference \\
\hline-.621 & 254 & .535 & -.82266 \\
\hline
\end{tabular}

Meanwhile, to strengthen the argument, a descriptive data comparison was carried out by the students' daily test scores in Biology learning on environmental material is taken from 131 students from 4 classes at grade 8 . The average results of the learning outcomes were 72.76 . The details of the results of learning the environmental material can be seen in Figure 2.

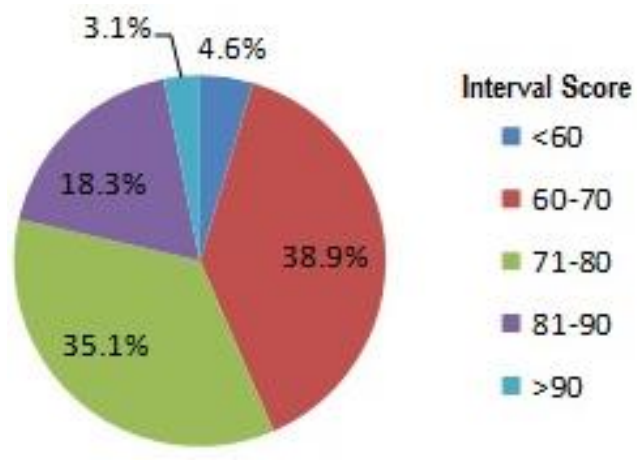

Figure 2. Percentage of students' environment learning outcomes

The results of the normality test show that the data are normally distributed, and the homogeneity test shows that the data is homogeneous. Based on the t-test it is known that the value of sig $>0.05$, this results in the acceptance of Ho. Scientifically, it can be interpreted that there is no difference in PEB scores in 7th and 8th-grade students. This shows that environment learning that has been obtained by 8th-grade students does not significantly influence the improvement of students' PEB. This is reinforced by data that shows that student learning outcomes in environmental material still tend to be many below the standard score (standard score for environment learning outcomes is 81). The percentage of students whose learning outcomes are still below standard score is $78.6 \%$. 
Biology learning on ecosystem/ environment material should be designed in such a way that there is an increasing effect in terms of students' PEB. The results of the study showed that there was no significant difference between grade 7 and grade 8 scores, plus learning outcomes of environmental material that was still much below the standard indicating that biology learning on environmental material had many shortcomings so evaluation must be carried out. This is because learning in the classroom does not have much impact on grade 8 students. Evaluation should involve various parties, including in this case evaluation in the form of feedback from students (Ho, MacGlashan, Littman, \& Cushman, 2017; Kinay \& Bagceci, 2016). Evaluation of learning can be seen in terms of learning plans, teaching materials, media used, teaching methods, or from the models used in the lesson. The teacher as the communicator must also continue to evaluate his understanding of various concepts (Owusu-Agyeman, Larbi-Siaw, Brenya, \& Anyidoho, 2017; Papadouris \& Constantinou, 2017; Siriwongs, 2015).

Ecosystem/environment learning in the classroom tends to only memorize environmental terms. In practice, students do not really understand and carry out environmental concepts, especially the concept of green consumerism. Teachers who explain the material also tend to ignore this aspect (Fitriani, Adisyahputra, \& Komala, 2018; Istiana \& Awaludin, 2018; Koutsoukos, Fragoulis, \& Valkanos, 2015; Suryanda, Azrai, \& Wari, 2016). In fact, if the environmental material that contains the concept of green consumerism is taught in depth in the material of the environment, it will likely increase the PEB of students. There are many fun ways that can be done in order to improve PEB students, one of them is by making an interesting media or game (Boholano, 2017; Morganti et al., 2017; Nugraini, Choo, Hin, \& Hoon, 2013). In addition, learning outcomes can be improved also by the application of learning models (Khoiriyah \& Husamah, 2018; Lince, 2016; Turnip, Wahyuni, \& Tanjung, 2016).

The media plays a role in delivering learning material. Likewise, in this case, the teacher can actually develop a learning media that contains green consumerism material (Mao, 2014; Nugraini et al., 2013; Panno et al., 2017). The goal is certainly so that students' knowledge of the concept of green consumerism is increasing. This is because the learning media is very helpful in delivering learning material (Ichsan, Dewi, Hermawati, \& Iriani, 2018; Jiang et al., 2017; Yusop \& Sumari, 2013). Student knowledge can increase if these green consumerism concepts are included in this environment learning. Increased knowledge of these concepts is very important in improving learning outcomes (Derevenskaia, 2014).

Pro-Environmental Behavior can be improved in many ways. This is because PEB is a thing that can be done by giving intervention in the form of treatment (Aguilar-Salinas, Ojeda-Benitez, Cruz-Sotelo, \& CastroRodríguez, 2017; Buzov, 2014; Ertz et al., 2016; Truelove \& Gillis, 2018). Learning is the most appropriate way to change PEB students (Ichsan, Sigit, \& Miarsyah, 2018; Tang, Geng, Schultz, Zhou, \& Xiang, 2017). One of them is through learning tools in this case specific learning media are discussed. Learning media in addition to improving learning outcomes can also improve PEB. This can happen because the media makes it easier for students to access information about green consumerism. When they want to see more green consumerism material, this can be done wherever they want. In addition to the media, many activities can be included in order to improve students' PEB such as ecotourism (Cheng et al., 2017; Hamden \& Low, 2015; Olaniyi, Akindele, \& Ogunjemite, 2018; Ting \& Cheng, 2017).

Environmental education is an effort in changing human behavior with the aim of developing understanding, skills, and public awareness regarding the environment so that people can care about the environment. Environmental caring behavior is very important to be owned by humans, because with caring behavior the environment will make environmental conditions to be maintained so that they can be passed on to the next generation. The environment is very suitable to be used as a learning tool because the natural environment provides a variety of materials that are in our daily activities. The environment can be a source of learning because learning not only uses books, but we can use the environment because the environment can provide various benefits for students, namely a) providing experience, b) providing knowledge, c) providing awareness about what people do to the environment, and d) knowing the importance of the environment as our life.

Environmental learning will make people grow their behavior in a number of ways, namely: a) respecting and nurturing life, b) improving the quality of human life, c) conserving the life force and diversity of the earth, d) avoiding waste of non-renewable resources, e) not exceeding capacity limits carrying capacity of the earth, f) change the attitude of life that is consumptive and excessive.

The implementation of environmental learning activities must be well designed and integrated so as not to overlap in the implementation of environmental learning. Environmental learning is also not only done in the school environment but can also be done. 
In addition to media, enhancing Biology learning outcomes can also be obtained by developing teaching materials. Development of teaching materials in Biology materials that are considered necessary can be done to improve learning outcomes (Azrai, Ernawati, \& Sulistianingrum, 2017; Garcia, 2015; Kamaludin, Surtikanti, \& Surakusumah, 2018; Quieng, Lim, \& Lucas, 2015; Sigit, Ernawati, \& Qibtiah, 2017). This also applies to environmental material, because this material is classified as a difficult material. In addition, teaching materials are also potential to improve students' PEB because they have functions similar to learning media. Electronic learning materials can also be accessed anywhere (Best \& MacGregor, 2017; Golitsyna, 2017; Reyna, Hanham, \& Meier, 2018).

\section{CONCLUSION}

Green consumerism learning in schools has not affected the students' pro-environmental behaviour (PEB). This is evidenced by the PEB score between 7th and 8th-grade students who are no different. Environmental learning outcomes are still relatively low, as many as $78.6 \%$ of students are still below the minimum standard of Biology subjects on environmental material. This is because there is little environmental learning in the class that discusses green consumerism. This resulted in an impact on the low PEB score and learning outcomes.

\section{REFERENCES}

Aguilar-Salinas, W., Ojeda-Benitez, S., Cruz-Sotelo, S., \& Castro-Rodríguez, J. (2017). Model to evaluate proenvironmental consumer practices. Environments, 4(1), 1-15. doi: https://doi.org/10.3390/environments 4010011

Akenji, L. (2014). Consumer scapegoatism and limits to green consumerism. Journal of Cleaner Production, 63, 13-23. doi: https://doi.org/10.1016/j.jclepro.2013.05.022

Azrai, E. P., Ernawati, E., \& Sulistianingrum, G. (2017). Pengaruh gaya belajar david kolb (divergen, assimilator, convergen, accommodator) terhadap hasil belajar siswa pada materi pencemaran lingkaran. Biosfer: Jurnal Pendidikan Biologi, 10(1), 9-16. doi: https://doi.org/https://doi.org/10.21009/ biosferjpb.10-1.2

Best, M., \& MacGregor, D. (2017). Transitioning design and technology education from physical classrooms to virtual spaces: implications for pre-service teacher education. International Journal of Technology and Design Education, 27(2), 201-213. doi: https://doi.org/10.1007/s10798-015-9350-z

Boholano, H. B. (2017). Smart social networking: 21st century teaching and learning skills. Research in Pedagogy, 7(1), 21-29. doi: https://doi.org/10.17810/2015.45

Burrascano, S., Chytrý, M., Kuemmerle, T., Giarrizzo, E., Luyssaert, S., Sabatini, F. M., \& Blasi, C. (2016). Current European policies are unlikely to jointly foster carbon sequestration and protect biodiversity. Biological Conservation, 201(May), 370-376. doi: https://doi.org/10.1016/j.biocon.2016.08.005

Buzov, I. (2014). Social network sites as area for students' pro-environmental activities. Procedia - Social and Behavioral Sciences, 152, 1233-1236. doi: https://doi.org/10.1016/j.sbspro.2014.09.304

Cheng, M., Wong, I. K. A., Wearing, S., \& McDonald, M. (2017). Ecotourism social media initiatives in China. Journal of Sustainable Tourism, 25(3), 416-432. doi: https://doi.org/10.1080/09669582.2016.1214141

Choudri, B. S., Baawain, M., Al-Zeidi, K., Al-Nofli, H., Al-Busaidi, R., \& Al-Fazari, K. (2017). Citizen perception on environmental responsibility of the corporate sector in rural areas. Environment, Development and Sustainability, 19(6), 2565-2576. doi: https://doi.org/10.1007/s10668-016-9855-y

Derevenskaia, O. (2014). Active learning methods in environmental education of students. Procedia - Social and Behavioral Sciences, 131, 101-104. doi: https://doi.org/10.1016/j.sbspro.2014.04.086

Ertz, M., Karakas, F., \& Sarigöllü, E. (2016). Exploring pro-environmental behaviors of consumers: an analysis of contextual factors, attitude, and behaviors. Journal of Business Research, 69(10), 3971-3980. doi: https://doi.org/10.1016/j.jbusres.2016.06.010

Fitriani, U., Adisyahputra, A., \& Komala, R. (2018). Eco-friendly website development in biology learning based on project activities on environmental pollution. Biosfer: Jurnal Pendidikan Biologi, 11(1), 32-46. doi: https://doi.org/https://doi.org/10.21009/biosferjpb.11-1.4

Garcia, L. C. (2015). Environmental science issues for higher- order thinking skills (HOTS) development: a case study in the Philippines. In Biology Education and Research in a Changing Planet (pp. 45-54). doi: https://doi.org/10.1007/978-981-287-524-2 
Golitsyna, I. (2017). Educational process in electronic information-educational environment. Procedia - Social and Behavioral Sciences, 237, 939-944. doi: https://doi.org/10.1016/j.sbspro.2017.02.132

Gündüz, A. Y., Alemdağ, E., Yaşar, S., \& Erdem, M. (2016). Design of a problem-based online learning environment and evaluation of its effectiveness. The Turkish Online Journal of Educational Technology, 15(3), 49-57. doi: https://doi.org/10.1017/CBO9781107415324.004

Hamden, M., \& Low, K. C. P. (2015). Ecotourism development in Brunei Darussalam. Transnational Corporations Review, 6(3), 248-272. doi: https://doi.org/10.5148/tncr.2014.6304

Haws, K. L., Winterich, K. P., \& Naylor, R. W. (2014). Seeing the world through GREEN-tinted glasses: green consumption values and responses to environmentally friendly products. Journal of Consumer Psychology, 24(3), 336-354. doi: https://doi.org/10.1016/j.jcps.2013.11.002

Ho, M. K., MacGlashan, J., Littman, M. L., \& Cushman, F. (2017). Social is special: a normative framework for teaching with and learning from evaluative feedback. Cognition, 167, 91-106. doi: https://doi.org/10. 1016/j.cognition.2017.03.006

Ichsan, I. Z., Dewi, A. K., Hermawati, F. M., \& Iriani, E. (2018). Pembelajaran IPA dan lingkungan: analisis kebutuhan media pembelajaran pada SD, SMP, SMA di Tambun Selatan, Bekasi. JIPVA (Jurnal Pendidikan IPA Veteran), 2(2), 131-140. doi: https://doi.org/10.31331/jipva.v2i2.682

Ichsan, I. Z., \& Mulyani, S. W. W. (2018). Improving students' motoric skills through demonstration method in recycling plastic waste. JPBI (Jurnal Pendidikan Biologi Indonesia), 4(2), 189-194. doi: https://doi.org/ 10.22219/jpbi.v4i2.5890

Ichsan, I. Z., Sigit, D. V., \& Miarsyah, M. (2018). Learning environment: gender profile of students' proenvironmental behavior (PEB) based on green consumerism. Tadris: Jurnal Keguruan Dan IImu Tarbiyah, 3(2), 97-107. doi: https://doi.org/10.24042/tadris.v3i2.3358

Istiana, R., \& Awaludin, M. T. (2018). Enhancing biology education students ability to solve problems in environmental science material through inquiri model-based lesson study. Biosfer: Jurnal Pendidikan Biologi, 11(1), 57-66. doi: https://doi.org/https://doi.org/10.21009/biosferjpb.11-1.6

Jiang, B., Yang, J., Lv, Z., Tian, K., Meng, Q., \& Yan, Y. (2017). Internet cross-media retrieval based on deep learning. Journal of Visual Communication and Image Representation, 48, 356-366. doi: https://doi.org/ 10.1016/j.jvcir.2017.02.011

Kaiser, F. G., \& Wilson, M. (2004). Goal-directed conservation behavior: the specific composition of a general performance. Personality and Individual Differences, 36(7), 1531-1544. doi: https://doi.org/10.1016/j. paid. 2003.06 .003

Kamaludin, S., Surtikanti, H. K., \& Surakusumah, W. (2018). Developing issue-based teaching materials to improve student learning outcomes in freshwater biology course. JPBI (Jurnal Pendidikan Biologi Indonesia), 4(2), 161-170. doi: https://doi.org/10.22219/jpbi.v4i2.5549

Khoiriyah, A. J., \& Husamah, H. (2018). Problem-based learning: creative thinking skills, problem-solving skills, and learning outcome of seventh grade students. JPBI (Jurnal Pendidikan Biologi Indonesia), 4(2), 151-160. doi: https://doi.org/10.22219/jpbi.v4i2.5804

Kinay, I., \& Bagceci, B. (2016). The investigation of the effects of authentic assessment approach on prospective teachers' problem-solving skills. International Education Studies, 9(8), 51-59. doi: https:/l doi.org/10.5539/ies.v9n8p51

Koutsoukos, M., Fragoulis, I., \& Valkanos, E. (2015). Connection of environmental education with application of experiential teaching methods: a case study from greece. International Education Studies, 8(4), 2328. doi: https://doi.org/10.5539/ies.v8n4p23

Lekakos, G., Vlachos, P., \& Koritos, C. (2014). Green is good but is usability better? consumer reactions to environmental initiatives in e-banking services. Ethics and Information Technology, 16(2), 103-117. doi: https://doi.org/10.1007/s10676-014-9337-6

Lince, R. (2016). Creative thinking ability to increase student mathematical of junior high school by applying models numbered heads together. Journal of Education and Practice, 7(6), 206-212. Retrieved from http://search.ebscohost.com/login.aspx?direct=true\&db=eric\&AN=EJ1092494\&site=ehost-live

Mao, J. (2014). Social media for learning: a mixed methods study on high school students' technology affordances and perspectives. Computers in Human Behavior, 33(1), 213-223. doi: https://doi.org/10. 1016/j.chb.2014.01.002

Margono, B. A., Potapov, P. V., Turubanova, S., Stolle, F., \& Hansen, M. C. (2014). Primary forest cover loss in indonesia over 2000-2012. Nature Climate Change, 4(8), 730-735. doi: https://doi.org/10.1038/nclima te2277 
McCarthy, B., \& Liu, H. B. (2017). Food waste and the "green" consumer. Australasian Marketing Journal, 25(2), 126-132. doi: https://doi.org/10.1016/j.ausmj.2017.04.007

Moisander, J. (2007). Motivational complexity of green consumerism. International Journal of Consumer Studies, 31(4), 404-409. doi: https://doi.org/10.1111/j.1470-6431.2007.00586.x

Morganti, L., Pallavicini, F., Cadel, E., Candelieri, A., Archetti, F., \& Mantovani, F. (2017). Gaming for Earth: serious games and gamification to engage consumers in pro-environmental behaviours for energy efficiency. Energy Research and Social Science, 29(April), 95-102. doi: https://doi.org/10.1016/j.erss. 2017.05.001

Nissim, Y., Weissblueth, E., Scott-Webber, L., \& Amar, S. (2016). The effect of a stimulating learning environment on pre-service teachers' motivation and 21st century skills. Journal of Education and Learning, 5(3), 29. doi: https://doi.org/10.5539/jel.v5n3p29

Nugraini, S. H., Choo, K. A., Hin, H. S., \& Hoon, T. S. (2013). Students' feedback of e-av biology website and the learning impact towards biology. Procedia - Social and Behavioral Sciences, 103, 860-869. doi: https://doi.org/10.1016/j.sbspro.2013.10.408

Olaniyi, O. E., Akindele, S. O., \& Ogunjemite, B. G. (2018). Ecotourism suitability of okomu and pendjari national parks ecotourism suitability of okomu and pendjari national parks. Anatolia, 29(4), 593-604. doi: https://doi.org/10.1080/13032917.2018.1486329

Owusu-Agyeman, Y., Larbi-Siaw, O., Brenya, B., \& Anyidoho, A. (2017). An embedded fuzzy analytic hierarchy process for evaluating lecturers' conceptions of teaching and learning. Studies in Educational Evaluation, 55(May), 46-57. doi: https://doi.org/10.1016/j.stueduc.2017.07.001

Panno, A., Giacomantonio, M., Carrus, G., Maricchiolo, F., Pirchio, S., \& Mannetti, L. (2017). Mindfulness, pro-environmental behavior, and belief in climate change: the mediating role of social dominance. Environment and Behavior, 50(8). doi: https://doi.org/10.1177/0013916517718887

Papadouris, N., \& Constantinou, C. P. (2017). Integrating the epistemic and ontological aspects of content knowledge in science teaching and learning. International Journal of Science Education, 39(6), 663682. doi: https://doi.org/10.1080/09500693.2017.1299950

Quieng, M. C., Lim, P. P., \& Lucas, M. R. D. (2015). 21st Century-based soft skills: spotlight on non-cognitive skills in a cognitive-laden dentistry program. European Journal of Contemporary Education, 11(1), 72 81. doi: https://doi.org/10.13187/ejced.2015.11.72

Reyna, J., Hanham, J., \& Meier, P. (2018). The Internet explosion, digital media principles and implications to communicate effectively in the digital space. E-Learning and Digital Media, 15(1), 36-52. doi: https://doi.org/10.1177/2042753018754361

Sandilos, L. E., Rimm-Kaufman, S. E., \& Cohen, J. J. (2017). Warmth and demand: the relation between students' perceptions of the classroom environment and achievement growth. Child Development, 88(4), 1321-1337. doi: https://doi.org/10.1111/cdev.12685

Sigit, D. V., Ernawati, E., \& Qibtiah, M. (2017). Hubungan pengetahuan lingkungan hidup dengan kemampuan pemecahan masalah pencemaran lingkungan pada siswa SMAN 6 Tangerang. Biosfer: Jurnal Pendidikan Biologi, 10(2), 1-6. doi: https://doi.org/10.21009/biosferjpb.10-2.1

Silva, D. A. L., Pavan, A. L. R., Oliveira, J. A. De, \& Ometto, A. R. (2015). Life cycle assessment of offset paper production in Brazil: hotspots and cleaner production alternatives. Journal of Cleaner Production, 93, 222-233. doi: https://doi.org/10.1016/j.jclepro.2015.01.030

Siriwongs, P. (2015). Developing students' learning ability by dint of self-directed learning. Procedia - Social and Behavioral Sciences, 197(February), 2074-2079. doi: https://doi.org/10.1016/j.sbspro.2015.07.577

Snake-Beings, E. (2017). "It"s on the tip of my google': intra-active performance and the non-totalising learning environment. E-Learning and Digital Media, 14(1-2), 38-51. doi: https://doi.org/10.1177/20427 53017692429

Suryanda, A., Azrai, E. P., \& Wari, N. (2016). Pengaruh penerapan model pembelajaran group investigation (GI) terhadap kemampuan berpikir analisis siswa pada materi pencemaran lingkungan. Biosfer: Jurnal Pendidikan Biologi, 9(2), 37-44. doi: https://doi.org/10.21009/biosferjpb.9-2.6

Tang, Y., Geng, L., Schultz, P. W., Zhou, K., \& Xiang, P. (2017). The effects of mindful learning on proenvironmental behavior: A self-expansion perspective. Consciousness and Cognition, 51, 140-148. doi: https://doi.org/10.1016/j.concog.2017.03.005

Ting, D. H., \& Cheng, C. F. C. (2017). Measuring the marginal effect of pro-environmental behaviour: guided learning and behavioural enhancement. Journal of Hospitality, Leisure, Sport and Tourism Education, 20(July 2015), 16-26. doi: https://doi.org/10.1016/j.jhlste.2016.12.001 
Truelove, H. B., \& Gillis, A. J. (2018). Perception of pro-environmental behavior. Global Environmental Change, 49(February), 175-185. doi: https://doi.org/10.1016/j.gloenvcha.2018.02.009

Turnip, B., Wahyuni, I., \& Tanjung, Y. I. (2016). The effect of inquiry training learning model based on just in time teaching for problem solving skill. Journal of Education and Practice, 7(15), 177-181. Retrieved from http://search.ebscohost.com/login.aspx?direct=true\&db=eric\&AN=EJ1103095\&site=ehost-live

Yusop, F. D., \& Sumari, M. (2013). The use of social media technologies among Malaysian youth. Procedia Social and Behavioral Sciences, 103, 1204-1209. doi: https://doi.org/10.1016/j.sbspro.2013.10.448 